\title{
Talin: Adherens Junction Protein Is Localized at the Epidermal-Dermal Interface in Skin
}

\author{
Hans W. Kaiser, ${ }^{*}$ Winfried Ness, ${ }^{*}$ Michael Offers, ${ }^{*}$ Edward J. O'Keefe, $†$ and Hans W. Kreysel* \\ 'Department of Dermatology, University of Bonn, Bonn, Germany; and †Department of Dermatology, University of North Carolina, \\ Chapel Hill, North Carolina, U.S.A.
}

The interaction between cells of the epidermis and the basal lamina is important for the integrity of the skin. Several hereditary and acquired diseases show changes at the dermalepidermal interface due to loss of adhesion between basal cells and the basement membrane. The structures mediating this interaction are hemidesmosomes, which have been extensively characterized by biochemical, molecular biologic, and morphologic techniques. Recently, however, a group of adhesion molecules that are distinct from hemidesmosomes and that mediate cell-matrix interactions was described in cultured fibroblasts, keratinocytes, and skin. These adhesion molecules, $\beta 1$ integrins, have been shown to be present in the focal adhesion, a cell-matrix contact associated with microfilaments rather than intermediate filaments characteristic of hemidesmosomes. In cultured cells, integrins of the $\beta 1 \mathrm{fam}-$ ily have been shown to be linked by a protein complex to actin filaments. In this study we describe the localization of talin, the binding protein for $\beta 1$ integrins, and vinculin at the dermal-epidermal interface in skin with immunofluorescence and immunoblotting techniques. These data suggest the presence of a link between the cytoplasmic actin filament system in basal keratinocytes and the extracellular matrix. Key words: talin/adherens junction/hemidesmosome/actin. J Invest Dermatol 101:789 - 793, 1993

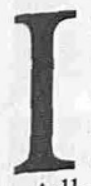

$\mathrm{n}$ addition to desmosomes and hemidesmomes, a second type of junction, which mediates cell-cell and cell-matrix contact and is generically called an adherens junction, has been found in fibroblasts [1-4], cultured keratinocytes [5-8] and other cultured cells (for reviews see $[9,10]$.

Adherens junctions show differences in electron microscopic structure [11] and in protein composition $[9,10,12]$ from tight junctions, gap junctions, and desmosomes and are present in two distinct locations, i.e., at sites of cell-cell and cell-matrix contact. Vinculin, a protein present in all types of adherens junction whether located at sites of cell-cell or cell-matrix contact, has recently been localized at areas of cell-cell and cell-matrix contact in human epidermis [13] and corneal epithelium [14]. A marked increase of vinculin at the epithelial-connective tissue interface was revealed by immunofluorescence during the healing process of corneal epithelium [14]. In this area of epidermal-dermal interface, integrins have also recently been localized in human skin $[15,16]$. Integrins are transmembrane proteins that associate with the adherens junction plaque [9] and hemidesmosomes [17]. The extracellular domain of integrins, depending upon the isoform of the $\alpha$ and $\beta$ subunits, can bind to extracellular matrix proteins including fibronectin, vitronectin, collagen, and laminin (for reviews see $[18,19]$. In the cytoplasmic domain, $\beta 1$ integrin can specifically bind to talin $[20]$.

It has previously been shown that talin also binds to vinculin $[21,22]$, which then can result in the binding of actin filaments to these plaques by association with $\alpha$ actinin $[23,24]$. These biochemical data indicate the structural continuity between actin and the extracellular matrix involving characteristic proteins as a mechanical linkage to transmembrane proteins.

Manuscript received January 25, 1993; accepted for publication June 8, 1993.

Reprint requests to: Dr. Hans W. Kaiser, Department of Dermatology, University of Bonn, Sigmund Freud Strasse 25, 5300 Bonn, Germany.

Abbreviation: DFP, diisopropylfluorophosphate.
We now report the presence of talin, a $215-\mathrm{kD}$ protein, at the epidermal-dermal junction in skin. Talin has been characterized as a protein of adhesion plaques [25] present only in areas of cell-matrix interaction and absent from areas of cell-cell contact [26]. We conclude that, in addition to proteins assembled in hemidesmosomes, talin and vinculin are candidates for microfilament-associated cellmatrix contact in skin.

\section{MATERIALS AND METHODS}

Cell Culture Human keratinocytes were obtained from foreskins of newborn infants and cultured according to methods previously described [5]. Human foreskin fibroblasts were initiated into culture according to Sly and Grubb [27]. Cells were grown in Dulbecco's modified Eagles's medium (DMEM) (Biochrom, Berlin, Germany) with the addition of $10 \%$ fetal bovine serum (Biochrom) and passaged every third day. Normal human keratinocytes and fibroblasts were plated in a density of $5000 \mathrm{cell} / \mathrm{cm}^{2}$ on eight-well tissue culture slides (ICN, Meckenheim, Germany) for immunofluorescence studies or in 100-mm culture dishes for immunoblot investiga-
tions.

Keratinocytes were grown for $3 \mathrm{~d}$ in MCDB 153 (Biochrom) [28] with essential supplements at $0.1 \mathrm{mM} \mathrm{Ca}{ }^{++}$. To compare the presence of talin and vinculin dependent on cell-cell contact, keratinocytes were induced to form cell-cell contact by addition of fresh medium containing $1.1 \mathrm{mM} \mathrm{Ca}^{++} 3 \mathrm{~h}$ before further processing.

Immunoblotting The presence of talin and vinculin was investigated in human foreskin fibroblasts, human cultured keratinocytes from foreskin, and human epidermis from upper thigh. Cultured human keratinocytes and fibroblasts were incubated with phosphate-buffered saline (PBS), $\mathrm{pH} 7.5$, containing $5 \mathrm{mM}$ ethylenediaminetetraacetic acid (EDTA) and $5 \mathrm{mM}$ diisopropylfluorophosphate (DFP) for $15 \mathrm{~min}$ at $4^{\circ} \mathrm{C}$ before being scraped off the dish with a rubber policeman. Normal human epidermis was obtained by placing biopsies in hot PBS $\left(95^{\circ} \mathrm{C}\right)$ with $2 \mathrm{mM}$ phenylmethylsulfonyl fluoride for $1 \mathrm{~min}$. Epidermis was collected with forceps, minced, and homogenized in Fairbanks' sample buffer [29]. Cells and tissues were dissolved in Fairbanks' sample buffer for $10 \mathrm{~min}$ at $68^{\circ} \mathrm{C}$. Proteins were separated on $1.5-\mathrm{mm}$-thick $3.5-17 \%$ exponential gradient slab gels in $0.2 \% \mathrm{w} / \mathrm{v}$ sodium dodecylsulfate (SDS) and transferred electrophoretically to PVDF 
membranes (Biorad, Munich, Germany) [30]. After reduction of nonspecific binding with $2 \%$ protease-free bovine serum albumin (BSA) (ICN) in PBS, $\mathrm{pH} 7.5$, for $4 \mathrm{~h}$ at room temperature, membranes were incubated overnight at $4^{\circ} \mathrm{C}$ with monoclonal antibodies against human uterus vinculin, $1: 10,000$ dilution (Sigma, Munich, Germany) and chicken gizzard talin, 1:2,000 dilution (Sigma), respectively, in PBS, $\mathrm{pH} 7.5$, containing 2\% BSA, and 0.1\% (v/v) Tween 20. Blots were washed with $0.2 \%$ Tween 20 in PBS, pH 7.5, followed by one washing with a buffer containing $2 \mathrm{M}$ urea, $1 \%$ (v/v) Triton $\mathrm{X}-100$, and $0.1 \mathrm{M}$ glycine, $\mathrm{pH} 8.2$, followed by one high-salt wash in $1 \mathrm{M}$ $\mathrm{NaCl}$ in PBS, $\mathrm{pH}$ 7.5. Final washes were performed with incubation buffer without BSA.

Goat-anti-mouse antibodies covalently coupled to horseradish peroxidase (Biorad) were applied for $90 \mathrm{~min}$ at $4^{\circ} \mathrm{C}$ in a dilution of 1:3000 in PBS, pH 7.5 , with $2 \%$ BSA. After several washings, bound antibodies were visualized with chemiluminescence (ECL, Amersham, Braunschweig, Germany) by exposing the membranes to Kodak XAR film.

Immunofluorescence Samples of skin were rapidly frozen in isopentane precooled with liquid nitrogen. Cryostat sections of $4-\mu \mathrm{m}$ thickness were sliced and mounted on ovalbumin-coated glass slides. Normal human keratinocytes and fibroblasts were fixed with $2 \%$ formalin for $10 \mathrm{~min}$ in PBS, $\mathrm{pH}$ 7.5 , and permeabilized with $0.2 \%$ Triton X-100 in PBS, pH 7.5. Sections and cells were incubated for $30 \mathrm{~min}$ at room temperature with $2 \% \mathrm{BSA}$ in PBS, $\mathrm{pH} 7.5$, and overnight with anti-human uterus vinculin antibodies (Sigma) at 1:4000 dilution and with anti-chicken gizzard talin antibodies (Sigma) at 1:200 dilution at $4^{\circ} \mathrm{C}$. After being washed in PBS, pH 7.5, containing $0.01 \%$ Tween, for $15 \mathrm{~min}$, slides were incubated with rhodamine-labeled goat-anti-mouse IgG (Dianova, Hamburg, Germany) at 1:200 dilution for $30 \mathrm{~min}$ at room temperature.

Slides were washed again with PBS, $\mathrm{pH} 7.5$, containing $0.1 \%$ Tween for $15 \mathrm{~min}$ and mounted in $40 \%$ glycerol in PBS, pH 7.5. Cells and sections were viewed with a Zeiss Axiophot equipped with epifluorescence, photographed with Kodak TRI-X film, and developed with Ultrafin SF (Tetenal, Norderstedt, Germany) at 400 ASA.

\section{RESULTS}

To evaluate the specific staining of the antibodies for focal adhesions, cultured fibroblasts were incubated with the monoclonal antibodies against vinculin (Fig $1 A$ ) and talin (Fig $1 B$ ). In fibroblasts these antibodies revealed an intensive longitudinal patchlike staining at the basal aspect of cells. In this region adherens junctions also designated as focal adhesions mediate the contact between cell and matrix [9].

In normal human keratinocytes cultured at reduced calcium concentration $(0.1 \mathrm{mM})$ to prevent the formation of intercellular junctions, vinculin could be detected only in areas of cell-matrix contact (Fig 1C). A higher density of these patches was noted at cell periphery. An identical distribution was found in keratinocytes with antibodies to talin (Fig 1D). To determine whether talin was present only in adherens junctions at the cell-matrix interface or was also present in adherens junctions at sites of cell-cell contact, the calcium concentration in the culture medium was increased to $1.1 \mathrm{mM}$ to induce the formation of cell-cell junctions. Immunofluorescence studies revealed that antibodies to talin crossreacted with patchlike structures only at the basal aspect of the keratinocyte membrane (Fig $1 F)$; staining was not noted at the lateral aspect of the cell membrane (Fig $1 H$ ). In contrast, antibodies to vinculin produced intense staining at the basal membrane of keratinocytes (Fig $1 E$ ) as well as at the lateral aspects of cell membranes in close contact with neighboring cells (Fig 1G).

A reduction in staining of vinculin and talin at the basal aspects of cells was noted at high extracellular calcium concentrations in comparison to keratinocytes fixed and stained after maintenance at a low concentration of calcium.

To study the distribution of talin in comparison to vinculin in skin, biopsies were obtained from healthy human skin from upper thigh, and cryostat sections of skin were incubated with antibodies against vinculin and talin. Antibodies against vinculin produced intense staining of the cell membrane in areas of cell-cell contact and at the dermal-epidermal interface (Figs $2 A, 3 A$ ). In contrast, antibodies against talin crossreacted exclusively in a continuous bandlike pattern at the epidermal-dermal junction (Fig 2B).

At higher magnification, staining for vinculin appeared discon-
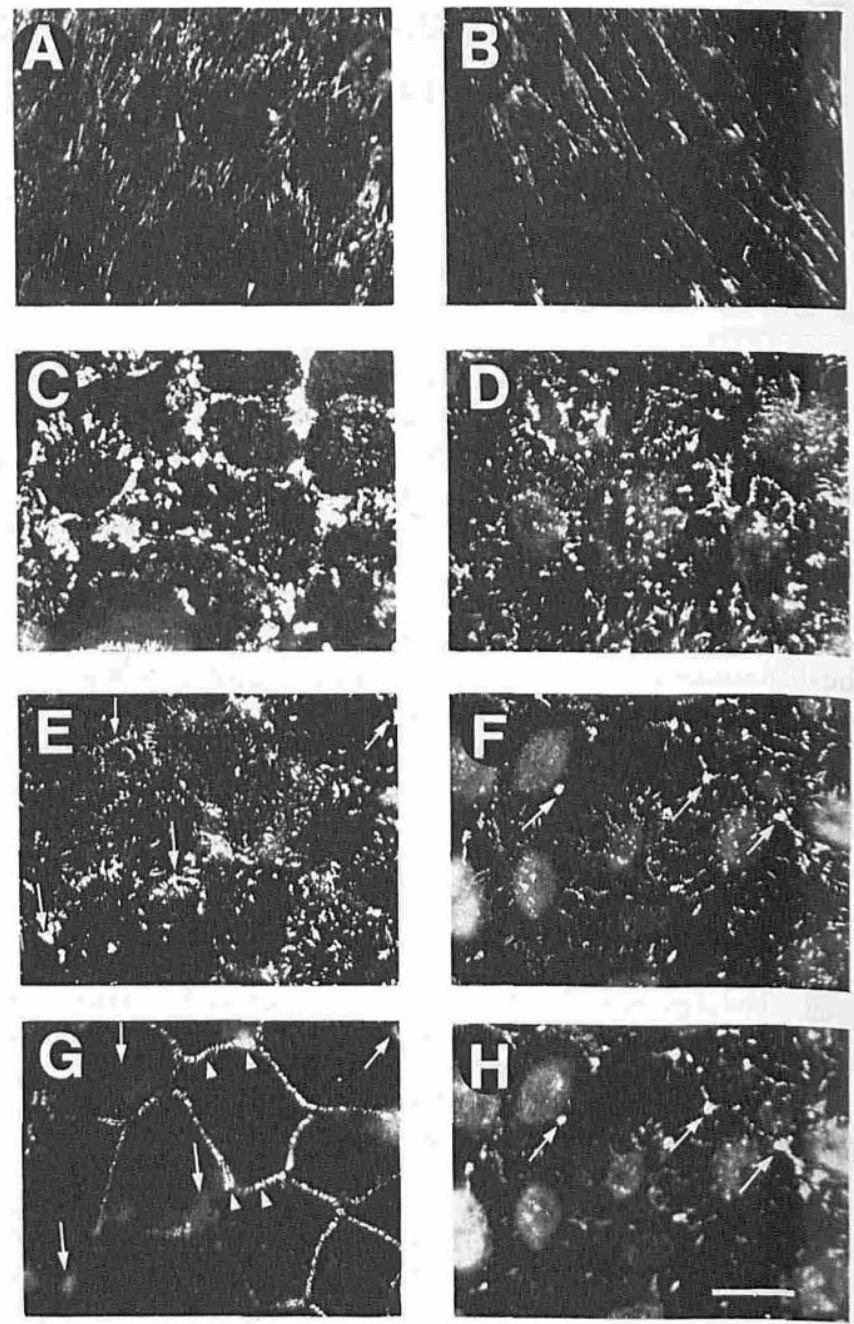

Figure 1. Localization of vinculin and talin in cultured human fibroblasts and normal human keratinocytes. Cells were stained with antibodies to vinculin $(A, C, E, G)$ or talin $(B, D, F, H)$ as in Materials and Methods. En face view, in $A-F$ the focal plane is at the base of cells at the junction of cell and substratum, in $G-H$ the focal plane is higher, at the level of cell-cell contact. $A, B$, human fibroblast; $C, D$, human keratinocytes cultured in reduced cal. cium concentration $(0.1 \mathrm{mM})$ and $E-H$, human keratinocytes cultured in high calcium concentration $(1.1 \mathrm{mM})$. Arrows, staining in the region of cell-matrix contact; arrowheads, staining in the region of cell-cell contact Bar, $30 \mu \mathrm{m}$.

tinuous in areas of cell-cell and cell-matrix contact (Fig 3A), consistent with the appearance of junctional structures. Antibodies to talin also displayed an interrupted bandlike pattern at the epidermal-dermal interface (Fig 3B).

The immunofluorescent findings were confirmed by immuno. blot analysis of the tissue. Skin from upper thigh (Fig 4, lanes 4 and 10), newborn foreskin (Fig 4, lanes 5 and 11), and arm skin (Fig 4, lanes 6 and 12) were separated by heat into dermis and epidermis to avoid contamination of the sample with fibroblasts derived from dermis. Epidermis was collected and lysed. Epidermal proteins sepa. rated by SDS gel electrophoresis and transferred to PVDF membranes showed a single band of staining at $130 \mathrm{kD}$ with antibodies against vinculin (Fig 4, lanes 4-6). This polypeptide band was also detected in human fibroblasts (Fig 4, lane 1) and in human keratinocytes cultured in low (Fig 4, lane 2) or high calcium concentration (Fig 4, lane 3 ). Antibodies against talin produced a single polypeptide band at $215 \mathrm{kD}$ in human fibroblasts (Fig 4, lane 7) and human keratinocytes cultured in low (Fig 4, lane 8) or high calcium con. 

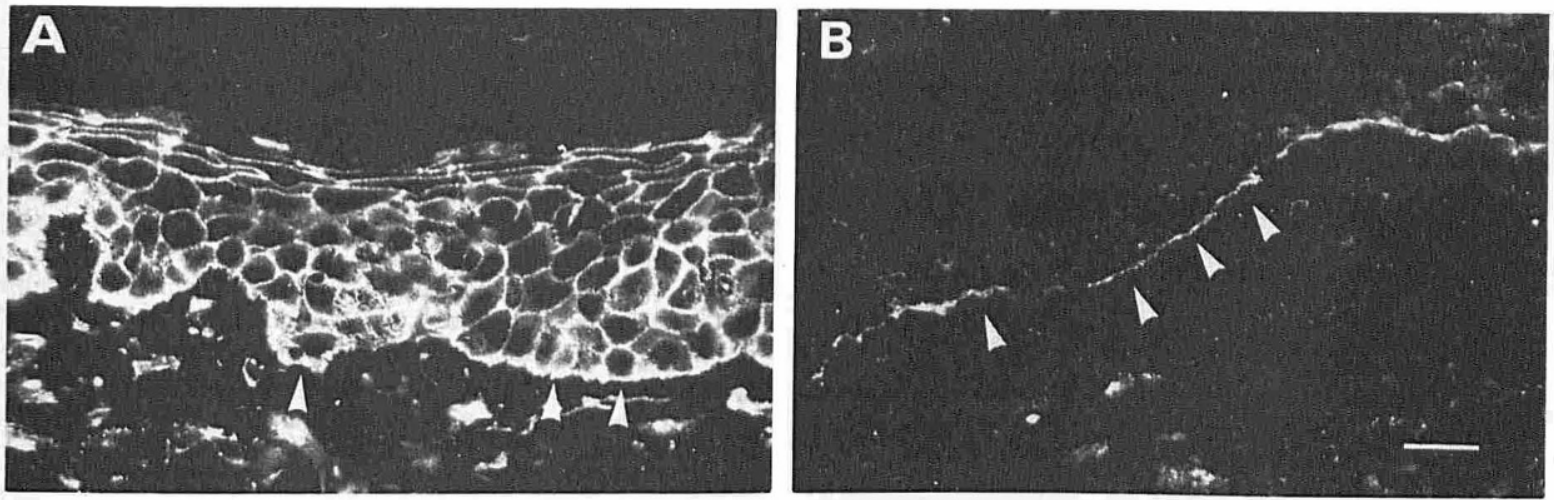

Figure 2. Expression of vinculin and talin in skin. Tissue was processed for immunofluorescence microscopy with antibodies to vinculin or talin as in Materials and Methods. Arrowheads, region of basement membrane staining. A, vinculin and B, talin. Bar, $25 \mu \mathrm{m}$.

centration (Fig 4, lane 9). In electrophoretically separated proteins of epidermis from upper thigh (Fig 4, lane 10), newborn foreskin (Fig 4, lane 11) and arm (Fig 4, lane 12), the single band detected by the antibodies comigrated with the bands detected in fibroblasts and in cultured human keratinocytes.

\section{DISCUSSION}

Antibody to talin recognized a $215-\mathrm{kD}$ polypeptide in an immunoblot of human epidermis, and a discontinuous bandlike staining pattern was visible in the dermal-epidermal junction by immunofluorescence. The distribution of this in vivo staining is consistent with the data obtained in cell culture. We conclude that the anti- body against talin specifically stained the epidermal-dermal junction. Here talin was identified to be present only in patchlike structures at sites of cell-matrix interaction and was not detectable at sites of cell-cell contact. It is well known that adherens junctions at sites of contact with the substratum are distinct in their protein composition from those at cell-cell contact sites [31,32], although vinculin $[2,5]$, actin [5,31], and $\alpha$ actinin [26,33] are detected in both subtypes of adherens junctions. In contrast, E-cadherin [34], plakoglobin [35], and catenin [36] have been reported to be present only at sites of cell-cell contact. Proteins known to be characteristic for cell-matrix junctions are integrins $[18,19]$ and talin $[32,38]$. Integrins have been located at the dermal-epidermal junction [17]. Although $\alpha 6 \beta 4$ integrin was detected in hemidesmosomes and colo-
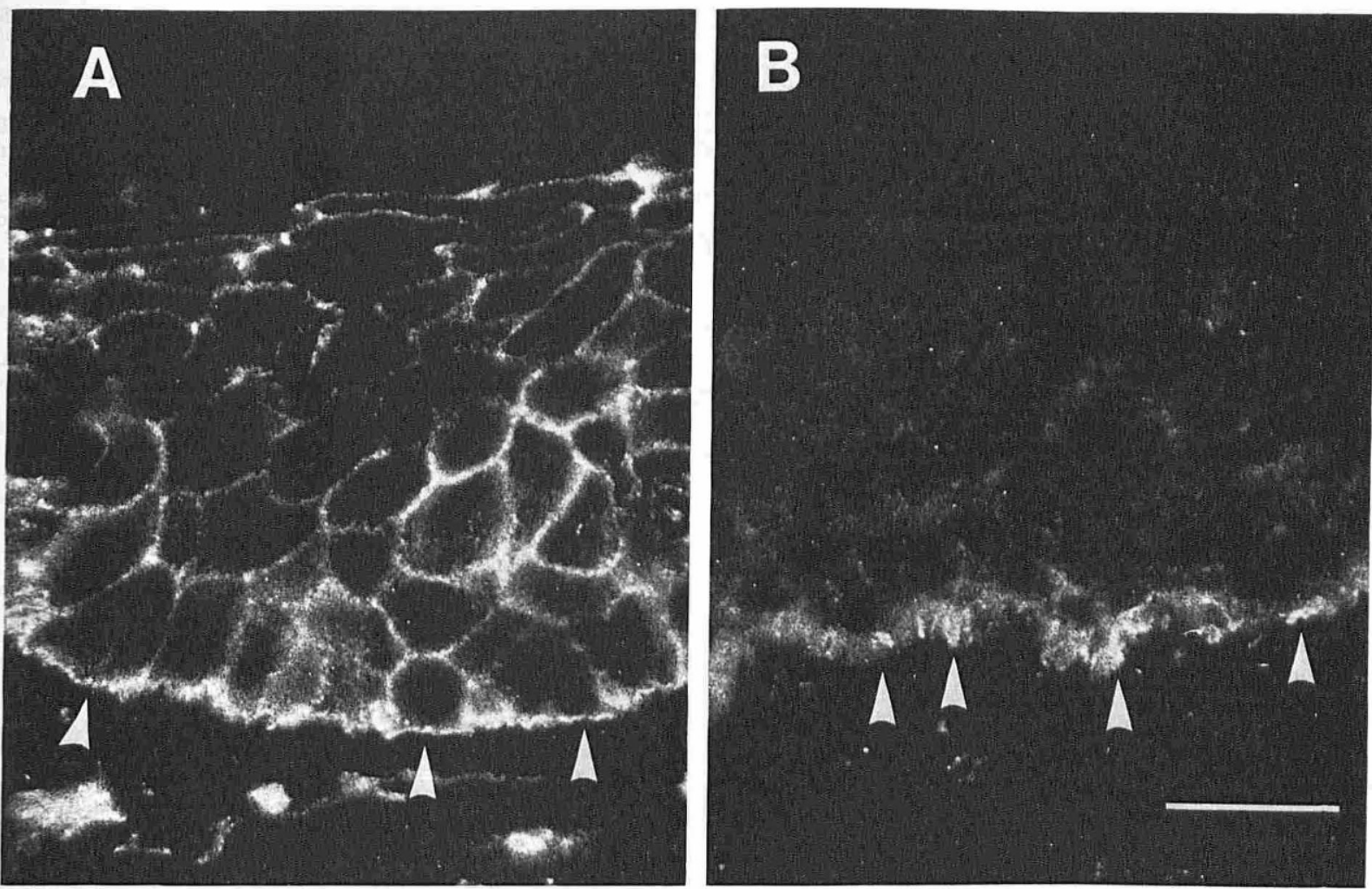

Figure 3. Expression of vinculin and talin in epithelium at higher magnification. Tissue was processed for immunofluorescence microscopy with antibodies to vinculin or talin as in Materials and Methods. Arrowheads, region of basement membrane staining $(A)$ for vinculin or $(B)$ for talin. An interrupted band-like taining is noted in the region of the basement membrane zone. Bar, $20 \mu \mathrm{m}$. 

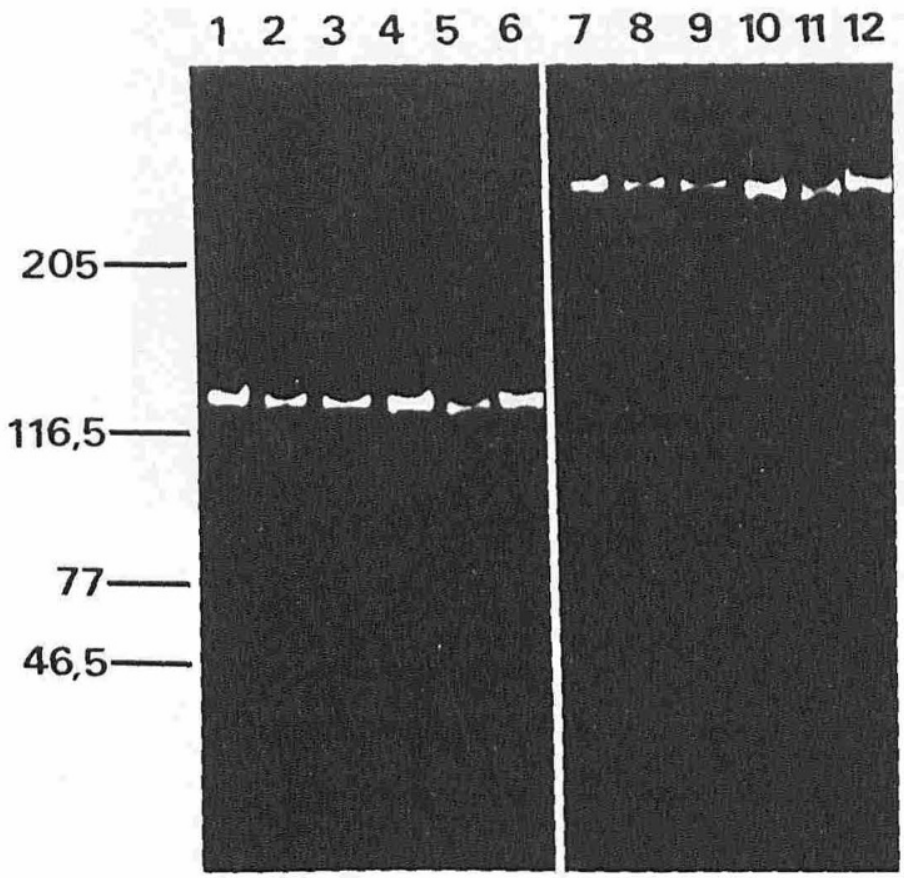

Figure 4. Demonstration of vinculin and talin in cells or epithelium by western blotting. Cell and tissue lysates were prepared as in Materials and Methods. Extracts of human fibroblasts (lanes 1 and 7), human keratinocytes at low calcium (0.1 mM) (lanes 2 and 8 ), and high-calcium medium (1.1 $\mathrm{mM}$ ) (lanes 3 and 9) and skin from upper thigh (lanes 4 and 10), newborn foreskin (lanes 5 and 11), and arm (lanes 6 and 12) were separated by SDS polyacrylamide gel electrophoresis, transferred to PVDF membrane, and probed with antibodies to vinculin (lanes 1-6) and talin (lanes 7-12). Numbers at left indicate molecular weight standards in $\mathrm{kD}$.

calized with the bullous pemphigoid antigen, $\alpha 2 \beta 1$ and $\alpha 3 \beta 1$ integrins were found to be adjacent to these structures. In a previous study, integrins $\alpha 2 \beta 1$ and $\alpha 3 \beta 1$ were identified in focal adhesions [16]. Talin transmits the interaction of microfilaments to integrins, and is regarded to be responsible for the immobilization of $\beta 1$ integrins in defined areas of the cell membrane's lipid bilayer. In biochemical assays talin shows low but specific binding affinity to $\beta 1$ integrins [20]. The native heterodimeric form of integrin, consisting of $\alpha$ and $\beta$ subunits, is required for talin-to-integrin binding [39]. Binding can be competitively inhibited with a 10 -amino-acid synthetic peptide corresponding to a sequence in the cytoplasmic domain of the $\beta 1$ subunit [40].

Another protein localized in adhesion plaques on the cytoplasmic site and known to bind to talin is vinculin. Talin has been found to bind to vinculin by different biochemical methods including gel filtration, co-immunoprecipitation, sucrose density gradient centrifugation, and a gel-overlay method $[20,21,41,42]$, although the interaction is of only moderate affinity [41]. The binding site for talin to vinculin was determined by transfection experiments to be limited to amino acids $167-207$ on the $90-\mathrm{kD}$ subunit of vinculin and may be regulated by the remaining $30-\mathrm{kD}$ vinculin-fragment, because the binding of the truncated $90-\mathrm{kD}$ protein to talin is three times greater than that of the intact protein.

The further link of the integrin-talin-vinculin complex to the microfilament cytoskeleton was thought to result from the direct interaction between actin and vinculin, but this is currently under renewed discussion (see [43] for review). However, $\alpha$-actinin has been shown to bind to vinculin as well as to actin, but may also form a direct link beween integrins and actin [44]. It thus represents a potential link between the microfilament cytoskeleton and the extracellular matrix $[21,42]$ and may be a component, responsible for the integrity of adherens junctions at the cell-matrix interface.
The results presented in this study support the presence of adherens junctions at the dermal-epidermal interface in addition to hemidesmosomes. It is therefore likely that, along with intermediate filaments, microfilaments participate in mediating cell-matrix contact in skin. The significance of such a microfilament-associated cell-matrix connection is far from being understood, but proteins such as protein kinase $C$ involved in cell signaling have been found in these junctional complexes [45]. Thus, a role for these structures in cell signaling is probable, because the presence of integrin-associated cell-matrix contact has been found to be a signal for cell differentiation, and because the phosphorylation of integrin leads to the dissociation of the integrin talin complex [38], suggesting that this may be an early event in modulating the strength of the cellmatrix interaction.

We are grateful to Andrea Balcerkiewicz for excellent technical assistance.

This work was supported in part by the Deutsche Forschungsgemeinschaft $K_{a}$ 852/1-1 to HWK and by NIH grant AM 25871 to EJO'K.

\section{REFERENCES}

1. Burridge K, Feramisco JR: Microinjection and localization of a $130 \mathrm{~K}$ protein in living fibroblasts: a relationship to actin and fibronectin. Cell 19:587-595, 1980

2. Geiger B: A $130 \mathrm{~K}$ protein from chicken gizzard: its localization at the termini of microfilament bundles in cultured chicken cells. Cell 18:193-205, 1979

3. Singer II, Paradiso PR: A transmembrane relationship between fibronectin and vinculin (130kd protein): serum modulation in normal and transformed hamster fibroblasts. Cell 24:481-492,1981

4. Feltkamp CA, Pijnenburg MAP, Roos E: Organization of talin and vinculin in adhesion plaques of wet-cleaved chicken embryo fibroblasts. $J$ Cell Science 100:579-587, 1991

5. O'Keefe EJ, Briggaman RA, Herman B: Calcium-induced assembly of adherens junctions in keratinocytes. J Cell Biol 105:807 - 817, 1987

6. Green KJ, Geiger B, Jones JCR, Talian JC, Goldman RD: The relationship between intermediate filaments and microfilaments before and during the formation of desmosomes and adherens-type junctions in mouse epidermal keratinocytes. J Cell Biol 104:1389-1402, 1987.

7. Kaiser HW, O'Keefe E, Bennett V: Adducin: Ca++-dependent association with sites of cell-cell contact. J Cell Biol 109:557-569, 1989

8. Kubler MD, Jordan PW, O'Neill CH, Watt FM: Changes in the abundance and distribution of actin and associated proteins during terminal differentiation of human epidermal keratinocytes. J Cell Science 100:153-165, 1991

9. Burridge K, Fath K, Kelly T, Nuckolls G, Turner C: Focal adhesions: transmembrane junctions between the extracellular matrix and the cytoskeleton. Anns Rev Cell Biol 4:487-525, 1988

10. Geiger B, Volk T, Volberg T, Bendori R: Molecular interactions in adherens-type contacts. J Cell Sci Suppl 8:251-272, 1987

11. Stachelin LA: Structure and function of intercellular junctions. Int Rev Cytol 39:191 - 283, 1974

12. Drenckhahn D, Franz H: Identification of actin-, $\alpha$-actinin-, and vinculin-containing plaques at the lateral membrane of epithelial cells. J Cell Biol 102:1843 1852, 1986

13. Kaiser HW, Ness W, Jungblut I, Briggaman RA, Kreysel HW, O'Keefe EJ: Adherens junctions: demonstration in human epidermis. $J$ Invest Dermatol 100:180-185, 1993

14. Zieske JD, Bukusoglu G, Gipson IK: Enhancement of vinculin synthesis by migrating stratified squamous epithelium. J Cell Biol 109:571-576, 1989

15. Ryynänen J, Jaakkola S, Engvall E, Peltonen J, Uitto J: Expression of $\beta 4$ integrins in human skin: comparison of epidermal distribution with $\beta 1$-integrin epitopes and modulation by calcium and vitamin $\mathrm{D}_{3}$ in cultured keratinocytes. $J$ Invest Dermatol 97:562-576, 1991

16. Carter WG, Wayner EA, Bouchard TS, Kaur P: The role of integrins $\alpha 2 \beta 1$ and $\alpha 3 \beta 1$ in cell-cell and cell-substrate adhesion of human epidermal cells. J Cell Biol 110:1387-1404, 1990

17. Carter WG, Kaur P, Gil SG, Gahr PJ, Wayner EA: Distinct functions for integrins $\alpha 3 \beta 1$ in focal adhesions and $\alpha 6 \beta 4$ /bullous pemphigoid antigen in a new stable anchoring contact (SAC) of keratinocytes: relation to hemidesmosomes.] Cell Biol 111:3141 - 3154, 1990

18. Ruoslahti E: Integrins. J Clin Invest $87: 1-5,1990$

19. Albelda SM: Endothelial and epithelial cell adhesion molecules. Am J Respir Cell Mol Biol 4:195-203, 1991

20. Horwitz A, Duggan K, Buck C, Beckerle MC, Burridge K: Interaction of plasma membrane fibronectin receptor with talin - a transmembrane linkage. Nature (Lond) 320:531-533, 1986

21. Burridge K, Mangeat $P:$ An interaction between vinculin and talin. Nature (Lond) 308:744-746, 1984 
22. Jones P, Jackson P, Price GJ, Patel B, Ohanion V, Lear AL, Critchley DR: Identification of a talin binding site in the cytoskeletal protein vinculin.J Cell Biol 109:2917-2927, 1989

23. Belkin AM, Koteliansky VE: Interaction of iodinated vinculin, metavinculin and $\alpha$-actinin with cytoskeletal proteins. FEBS Lett 220:291 - 294, 1987

24. Wachsstock DH, Wilkins JA, Lin S: Specific interaction of vinculin with $\alpha$-actinin. Biochem Biophys Res Commun 146:554-560, 1987

25. Burridge K, Connell L: A new protein of adhesion plaques and ruffling membranes. J Cell Biol 97:359-367, 1983

26. Geiger B, Ginsberg D: The cytoplasmic domain of adherens-type junctions. Cell Motil Cytoskeleton 20:1-6, 1991

27. Sly WS, Grubb J: Isolation of fibroblasts from patients. Methods Enzymol 58:444 450,1979

8. Boyce ST, Ham RG: Calcium-regulated differentiation of normal human epidermal keratinocytes in chemically defined clonal culture and serum-free serial culture. J Invest Dermatol 81:33S-40S, 1983

9. Fairbanks G, Steck TL, Wallach DFH: Electrophoretic analysis of the major polypeptides of the human erythrocyte membrane. Biochem 10:2606-2617, 1971

30. Towbin H, Staehelin T, Gordon J: Electrophoretic transfer of proteins from polyacrylamide gels to nitrocellulose sheets: procedure and some applications. Proc Natl Acad Sci USA 76:4350-4354, 1979

31. Geiger B, Volk T, Volberg T: Molecular heterogeneity of adherens junctions. $J$ Cell Biol 101:1523-1531, 1985

32. Drenckhahn D, Beckerle M, Burridge $\mathrm{K}$, Otto J: Identification and subcellular location of talin in various cell types and tissues by means of [ $\left.{ }^{125} \mathrm{I}\right]$ vinculin overlay, immunoblotting and immunocytochemistry. Eur J Cell Biol 46:513522,1988
33. Lazarides E, Burridge $\mathrm{K}$ : $\alpha$-Actinin: immunofluorescent localization of a muscle structural protein in nonmuscle cells. Cell 6:289-298, 1975

34. Takeichi M: Cadherins: a molecular family essential for selective cell-cell adhesion and animal morphogenesis. Trends Genet 3:213-217, 1987

35. Cowin P, Kapprell HP, Franke WW, Tamkun J, Hynes RO: Plakoglobin: a protein common to different kinds of intercellular adhering junctions. Cell 46:1063-1073, 1986

36. Kemler R, Ozawa M: Uvomorulin-catenin complex: cytoplasmic anchorage of a $\mathrm{Ca}^{2+}$-dependent cell adhesion molecule. Bioessays 11:88-91, 1989

37. Gumbiner B, Simons K: A functional assay for proteins involved in establishing an epithelial occluding barrier: identification of a uvomorulin-like polypeptide.J Cell Biol 102:457-468, 1986

38. Beckerle MC, Yeh RK: Talin: role at sites of cell-substratum adhesion. Cell Motil Cytoskeleton 16:7-13, 1990

39. Buck CA, Shea E, Duggan K, Horwitz AF: Integrin (the CSAT antigen): functionality requires oligomeric integrity. J Cell Biol 103:2421-2428, 1986

40. Buck CA, Horwitz AF: Integrin, a transmembrane glycoprotein complex mediating cell-substratum adhesion. J Cell Sci (suppl) 8:231-250, 1987

41. Otto JJ: Detection of vinculin-binding proteins with an ${ }^{125} \mathrm{I}$-vinculin gel overlay technique. J Cell Biol 97:1283-1287, 1983

42. Wilkins JA, Chen KY, Lin S: Detection of high molecular weight vinculin binding proteins in muscle and non-muscle tissues with an electroblot-overlay technique. Biochem Biophy Res Commun 116:1026-1032, 1983

43. Otto JJ: Vinculin. Cell Motil Cytoskeleton 16:1-6,1990

44. Otey CA, Pavalko FM, Burridge K: An interaction between alpha-actinin and the beta 1 integrin subunit in vitro. J Cell Biol 111:721 -729, 1990

45. Jaken S, Leach K, Klauck T: Association of type 3 protein kinase $C$ with focal contacts in rat embryo fibroblasts. J Cell Biol 109:697-704, 1989 